\title{
Prescription pattern in public specialized dental care centers in Brazil
}

\author{
Padrão de prescrição em centros especializados de atendimento odlontológico no Brasil \\ Patrón de prescripción en centros de atención odontológica especializados en Brasil
}

Received: 09/17/2021 | Reviewed: 09/26/2021 | Accept: 09/28/2021| Published: 10/01/2021

Gabriela Luiza Hochscheidt

ORCID: https://orcid.org/0000-0002-9898-3142 Federal University of Rio Grande do Sul, Brazil

E-mail: gabiluh@hotmail.com

Mateus Müller da Silva

ORCID: https://orcid.org/0000-0001-7417-3201

E-mail: mateus18muller@gmail.com

Federal University of Rio Grande do Sul, Brazil

Maria Beatriz Cardoso Ferreira

ORCID: https://orcid.org/0000-0002-6814-6773 Federal University of Rio Grande do Sul, Brazil E-mail: mariabea@ufrgs.br

Alexandre Silva de Quevedo

ORCID: https://orcid.org/0000-0001-5613-8015 Federal University of Rio Grande do Sul, Brazil E-mail: quevedoalexandre@ hotmail.com

Deise Ponzoni

ORCID: https://orcid.org/0000-0003-2855-7495 University of Rio Grande do Sul, Brazil E-mail: deise.ponzoni@ufrgs.br

\begin{abstract}
The aim of this study was to evaluate the most common drugs prescribed by dentists and the indicators related to rational drug use. A prospective cross-sectional study was conducted in which 189 interviews were carried out from August 2015 to June 2016 with patients who received drug prescriptions at specialized dental care centers in a city in southern Brazil. A specific data sheet was used, with questions regarding: age and gender of the patient, dental specialty in which the care occurred, and prescription drugs and their respective dosage regimen. Statistical analysis was performed using the chi-square test or Fisher's exact test $(\mathrm{p}<0.05)$. From the total of interviews, it was observed that $92.1 \%$ of patients received written medication prescriptions. Of these prescriptions, $38.5 \%$ had some type of antibiotic for systemic use. Acetaminophen was the most prescribed drug (33.4\%), followed by amoxicillin (19.7\%). The mean number of medications per prescription was 1.75 , and $17.4 \%$ of the prescriptions did not indicate the dosage regimen. Our findings indicate a high incidence of prescribed antibiotics and non-compliance with regulatory agency guidance in prescriptions at the centers evaluated.
\end{abstract}

Keywords: Drug prescriptions; Dentists; Public health dentistry.

\section{Resumo}

O objetivo deste estudo foi avaliar os medicamentos mais comumente prescritos por cirurgiões-dentistas e os indicadores relacionados ao uso racional de medicamentos. Foi realizado um estudo transversal, prospectivo, no qual foram realizadas 189 entrevistas, no período de agosto de 2015 a junho de 2016, com pacientes que receberam prescrição de medicamentos em centros especializados de atendimento odontológico de um município do sul do Brasil. Foi utilizada uma ficha específica, contendo questões referentes a: idade e sexo do paciente, especialidade odontológica em que ocorreu o atendimento e medicamentos prescritos e seus respectivos regimes posológicos. A análise estatística foi realizada por meio do teste do qui-quadrado ou teste exato de Fisher $(\mathrm{p}<0,05)$. Do total de entrevistas, observou-se que $92,1 \%$ dos pacientes receberam prescrição de medicamentos por escrito. Dessas prescrições, 38,5\% apresentavam algum tipo de antibiótico de uso sistêmico. O paracetamol foi o medicamento mais prescrito (33,4\%), seguido da amoxicilina (19,7\%). O número médio de medicamentos por prescrição foi de $1,75 \mathrm{e}$ $17,4 \%$ das prescrições não indicavam o esquema posológico. Nossos resultados indicam uma alta incidência de antibióticos prescritos e não conformidade com as orientações das agências reguladoras nas prescrições nos centros avaliados.

Palavras-chave: Prescrições de medicamentos; Odontológos; Odontologia em saúde pública.

\section{Resumen}

El objetivo de este estudio fue evaluar los medicamentos más comunes prescritos por los cirujanos dentistas y los indicadores relacionados con el uso racional de medicamentos. Se realizó un estudio prospectivo transversal en el que 
se realizaron 189 entrevistas desde agosto de 2015 a junio de 2016 a pacientes que recibieron prescripción de medicamentos en centros de atención odontológica especializados en una ciudad del sur de Brasil. Se utilizó una hoja de datos específica, con preguntas sobre: edad y sexo del paciente, especialidad odontológica en la que se realizó la atención y medicamentos recetados y su respectivo régimen de dosificación. El análisis estadístico se realizó mediante la prueba de chi-cuadrado o la prueba exacta de Fisher ( $\mathrm{p}<0,05)$. Del total de entrevistas, se observó que el 92,1\% de los pacientes recibieron prescripción de medicamentos por escrito. De estas prescripciones, el 38,5\% tenía algún tipo de antibiótico de uso sistémico. El paracetamol fue el fármaco más prescrito $(33,4 \%)$, seguido de la amoxicilina $(19,7 \%)$. El número medio de medicamentos por prescripción fue de 1,75 y el 17,4\% de las prescripciones no indicaron la pauta posológica. Nuestros hallazgos indican una alta incidencia de antibióticos prescritos y el incumplimiento de la orientación de la agencia reguladora en las prescripciones en los centros evaluados.

Palabras clave: Prescripciones de medicamentos; Odontológos; Odontología en salud pública.

\section{Introduction}

Dental practice requires the prescription of medications for the management of pain, inflammation and infection. Evaluation and monitoring of rational drug use in Brazil is carried out by the National Committee for the Promotion of Rational Drug Use (Brasil, 2013).

According to the World Health Organization (WHO), rational drug use is when the patient receives the appropriate medication for the clinical situation, in doses that are appropriate for the patient's needs, to be taken for a convenient time period and at the lowest possible cost to the patient and the community. Indiscriminate drug use can cause harm to patients without necessarily achieving their therapeutic goal. In the use of antibiotics, this concern is even greater due to the development of drug resistance, where it is considered by the WHO one of the most serious public health problems in the world (Ahsan et al., 2020; Lisboa, Martins, Castilho, Souza e Silva, \& Abreu, 2015; Thompson, Rios, Fedorowicz, Dailey, \& Douglas, 2018; World Health Organization, 2018).

About $40 \%$ of dentists in England prescribe prophylactic antibiotics to patients with no relevant clinical history to prevent postoperative infection (Palmer, Pealing, Ireland, \& Martin, 2000). Studies show that amoxicillin and metronidazole are the antibiotics most commonly prescribed by dentists (Al-Haroni \& Skaug, 2007; De-Paula, Silveira, Fagundes, Ferreira, \& Montagner, 2014; Palmer, Martin, Pealing, \& Ireland, 2000). There are few studies regarding analgesics and antiinflammatory drugs. Dipyrone, acetaminophen, diclofenac, ibuprofen and nimesulide are the most prescribed (Castilho, Paixão, \& Perini, 1999; De-Paula et al., 2014; Poveda Roda, Bagán, Jiménez Soriano, \& Gallud Romero, 2007; Rauniar, Das, Manandhar, \& Bhattacharya, 2012).

In Brazil, many prescription drugs in public services are free to patients, which could facilitate access and indiscriminate use, and generate excessive costs for the public health system. The aim of this study was to determine the drugs most commonly prescribed by dentists and the indicators related to rational drug use.

\section{Methodology}

The present cross-sectional prospective study was approved by the Institutional Research Board and Ethics Committee in Research (Project No. 1.009.541) at the Universidade Federal do Rio Grande do Sul (Porto Alegre, RS, Brazil) and by the Ethics Committee of the Municipal Government of Porto Alegre (Project No. 1.056.479). Data were collected from interviews with patients who received medication prescriptions, shortly after being seen at specialized dental care centers in a city in southern Brazil. All patients who agreed to participate in the study signed an informed consent form. Prescription indicators of the WHO and national regulations were used (Portaria n ${ }^{\circ}$ 834, 2013; World Health Organization, 1993; World Health Organization, 2018).

The sample, obtained for convenience during the research period, corresponded on average to $40 \%$ of the total number of visits in the period for each center of specialties. Data were collected by a single dentist, a master student, from a structured 
questionnaire, in the period from June to August 2016. Calibration was not performed. The questionnaire allowed the identification of one of the six centers of dental specialties and their association or not to a higher education institution; and the specialty in which the service took place (oral and maxillofacial surgery and trauma, endodontics, periodontics and oral medicine). Furthermore, variables of interest such as the prescription or not of medication(s), and if so, the prescription scheme (pharmaceutical form and concentration, dose, route and interval of administration, treatment time) were collected. The questionnaire also registered whether the patient received any verbal recommendation to use the medication(s) and if so, it was registered. Additional demographic data such as the patient's date of birth and the patient's gender were collected. All data were collected and tabulated in the EpiData v1.5 program (EpiData Association, Odense, Denmark). In addition, the information of age and gender of the clinicians were registered to analyze possible influences on the clinical conduct.

Descriptive statistical analysis was performed for all variables collected and expressed as percentages. To evaluate the number of antibiotic prescriptions by different dental care centers (linked or non-linked to a higher education institution), the frequency of prescriptions in the two types of institutions was compared using the chi-square test. The null hypothesis was that there was independence between the relative frequencies of the variables. Statistical analysis was performed using the chisquare test $(\mathrm{p}<0.05)$. Analysis of the results was performed with SPSS v20.0 for Mac (IBM® SPSS Statistics, New York, USA).

\section{Results}

There were 189 interviews after a dental appointment in which some type of medication was prescribed or recommended. The mean age of the patients was 38.34 years (SD \pm 15.57 ) and 69.3\% were women. All interviews were conducted with patients older than 18 years.

The dental specialty that prescribed medications the most was oral and maxillofacial surgery and trauma (67.2\%), followed by oral medicine (14.3\%), periodontics (13.2\%) and endodontics (5.3\%).

From the total interviews, we found that $92.1 \%$ of patients received prescriptions and $7.9 \%$ received only oral recommendations for drug administration. Of those who received prescriptions, $6.3 \%$ also received oral recommendations for other non-prescription medications. Of the total medications recommended orally, acetaminophen was the most common, and in this situation, patients did not know the dose and frequency of administration.

Among the patients given prescriptions, the most prescribed non-opioid analgesic was acetaminophen (53.9\%), followed by dipyrone $(0.06 \%)$. The prescribed anti-inflammatory drugs were ibuprofen $(22 \%)$ and nimesulide $(8.5 \%)$.

Of the total prescriptions, $38.5 \%$ included some type of antibiotic for systemic use. Amoxicillin was the most prescribed systemic antibiotic, where it was included in $34.5 \%$ of all prescriptions. Other prescribed antibiotics were amoxicillin with clavulanate, azithromycin, clindamycin, erythromycin and metronidazole (representing less than $9 \%$ of total antibiotics). Most systemic antibiotics were prescribed with dosage regimen. Those prescribed in a prophylactic regimen had the wrong administration regimen, except one prescription with the correct dose and administration time. Comparing the number of antibiotic prescriptions from a specialized dental care center linked to a higher education institution (11.8\%) with other non-linked centers $(43.6 \%)$, there was a significant difference $\left(\chi^{2}=11.826, p<0,001\right)$.

Most drugs (98.7\%) were prescribed according to pharmacological nomenclature. Chlorhexidine, when indicated as a mouthwash, despite being a topical antiseptic, was only recommended orally in some situations.

Regarding the duration of the treatments, $17.4 \%$ of the medications did not state the administration frequency, and $12.4 \%$ were prescribed for "if and when there is pain," without additional guidance.

The mean number of prescription drugs was 1.75. Prescriptions containing three or four drugs represented $24.7 \%$ of the total value. A total of 305 medications were prescribed (Table 1), and $79 \%$ were on the municipality's list of essential 
medicines (Porto Alegre, 2020). Among those not on the list of essential drugs, chlorhexidine (10.8\%) and nimesulide (5.2\%) were the most prominent.

Table 1. Pharmacological groups and prescription drugs at specialized dental centers. See numbers.

\begin{tabular}{ll}
\hline \multicolumn{1}{c}{ Drug group (\%) } & \multicolumn{1}{c}{ Drugs (\%) } \\
\hline Antibiotics (32.8\%) & Amoxicillin (19.7\%), Chlorhexidine (10.8\%) \\
Analgesics (43.9\%) & Acetaminophen (33.4\%), Dipyrone (7.5\%), Codeine \\
& $(3 \%)$ \\
Antiinflammatories (19.3\%) & Ibuprofen (13.7\%), Nimesulide (5.2\%) \\
Others $(3.9 \%)$ & Fluconazole (1\%)
\end{tabular}

Source: Authors.

The most prescribed antibiotic was amoxicillin $(19,7 \%)$, the most prescribed analgesic was acetaminophen $(33,4 \%)$ and the most prescribed anti-inflammatory was ibuprofen $(13,7 \%)$.

\section{Discussion}

Drug use entails a cost associated with health care as well as potential for the development of drug abuse and microbial resistance. This study aimed to evaluate the pattern of prescriptions received by patients who were seen at specialized dental care centers in a city in southern Brazil, whether or not linked to a higher education institution.

The mean number of medications observed in the sample was 1.75 medications per prescription. The WHO recommends that prescriptions contain a two-drug limit (World Health Organization, 2018). Only 24.7\% of prescriptions had more than two prescription drugs. In most of these, three prescription drugs and at most four were observed. The WHO also suggests prescribing generic drugs that are part of the list of essential drugs to determine compliance with national drug policy (World Health Organization, 2018). In Brazil, by law, medical and dental drug prescriptions, within the scope of the Unified Health System (SUS), must adopt the Brazilian Common Denomination or, in its absence, the International Common Denomination (Lei $\mathrm{n}^{\circ}$ 9.787, 1999). In this study, $98.7 \%$ of the drugs had the generic denomination and $79 \%$ of the prescribed drugs were on the municipality's list of essential medicines.

Regarding the duration of the prescribed treatments, there was a considerable incidence of prescriptions without treatment time indicated (17.4\%) or with "if necessary" regimen indicated (12.4\%). According to the protocols of national regulatory agencies prescriptions should specify the treatment time to avoid continuous use without indication and to determine when the patient needs to be reevaluated, if symptoms do not subside within the indicated time. The use of vague expressions should be avoided and, where necessary, should be accompanied by clear additional information such as the maximum allowable daily dose and conditions that determine the use or discontinuation of treatment (Teoh, Stewart, Marino, \& McCullough, 2018).

Some of the patients interviewed (13.8\%) received oral information for medication use. In general, these practices are not appropriate due to the high risk of administration errors. They are restricted only to emergency situations, where medications will be prescribed later (Teoh et al., 2018). 
Although there are no defined limits on the number of prescriptions that have antibiotics, we believe that the rate of systemic antibiotics prescribed was high (38.5\%), considering the elective nature of the procedures, most commonly performed in the specialized dental care centers evaluated in the study.

We found that the most prescribed antibiotic was amoxicillin, as in other countries as well, such as Australia, Spain, Belgium and Turkey (Mainjot, D'Hoore, Vanheusden, \& Van Nieuwenhuysen, 2009; Segura-Egea et al., 2010; Teoh et al., 2018; Koyuncuoglu et al., 2017). In Germany, the most prescribed antibiotic is reported to be clindamycin, followed by penicillins (Hussein, Krohn, Kaufmann-Kolle, \& Willms, 2017). Different studies in different countries have shown that the prescription rate of antibiotics is high and their use is indiscriminate (Ahsan et al. 2020; Al-Haroni, \& Skaug, 2007; Hussein, Krohn, Kaufmann-Kolle, \& Willms, 2017; Koyuncuoglu et al., 2017; Lisboa et al. 2015; Mainjot et al., 2009 ; Palmer et al. 2000; Segura-Egea et al., 2010; Teoh et al., 2018). Inappropriate antibiotic prescription is associated with the indication and administration regimen. Non-clinical factors also appear to influence dentists' prescribing practices, including patient expectancy, patient convenience and social background (Dar-Odeh, Abu-Hammad, Al-Omiri, Khraisat, \& Shehabi, 2010; Stein et al. 2018).

A statistically significant difference was observed in the frequency of antibiotic prescription in the centers linked to an educational institution and the others, since the prescriptions were guided by university professors. Patients cared for at these study centers should have already been evaluated in primary care services, where they would have already received treatment for acute infectious processes. The most common procedures performed at these centers are the removal of impacted teeth, biopsy of mouth lesions, periodontal treatment and endodontic treatment. Most antibiotics were prescribed to avoid the risk of infection spreading or to prevent postoperative infections.

Several studies have shown different results regarding the efficacy of antibiotics in preventing postoperative wound infections (Arteagoitia, Diez, Barbier, Santamaría, \& Santamaría, 2005; Ataoğlu, Oz, Candirli, \& Kiziloğlu, 2008; Kaczmarzyk et. al, 2007; Lacasa et al., 2007). In this study, the doses and time of use prescribed for antibiotic prophylaxis appeared to be wrong, corroborating the findings of Lisboa et al. (2015), who found that only $13.2 \%$ of antibiotic prophylaxis prescriptions were completely correct. One study reported that doses starting in the preoperative period were effective in reducing postoperative infection after third molar removal, although 25 patients needed to be treated to prevent infection, and that the use of antibiotics only postoperatively had no statistically significant effects on the frequency of infections (Ren \& Malmstrom, 2007). Considering the antimicrobial resistance factors and adverse effects of these agents, the benefits of antibiotic prophylaxis in the removal of impacted teeth are unclear and should be considered responsibly by oral surgeons. For other minor oral surgery procedures, such as tooth extraction, biopsy, frenectomy, torus removal and clinical crown augmentation, the use of antibiotics has no benefit, since the incidence of infection is low. The evidence in support antibiotic use for these procedures is minimal and inconsistent. Moreover, the maintenance of aseptic conditions, combined with the surgical principles of atraumatic tissue manipulation, should not be overlooked in favor of oral antibiotics (Hupp, Ellis III \& Tucker, 2015; Stein et al. 2018; Thompson et al. 2018; Wannmacher, \& Ferreira, 2007).

In periodontics, antibiotic chemotherapy should be restricted to cases of recurrent periodontitis not responsive to mechanical instrumentation and aggressive periodontitis, where host defenses are compromised (Kaczmarzyk et. al, 2007). No differences were shown in non-surgical periodontal therapy with and without systemic antibiotics, especially when compared over a period of six months to a year (Keestra, Grosjean, Coucke, Quirynen, \& Teughels, 2015; Mombelli, Almaghlouth, Cionca, Courvoisier, \& Giannopoulou, 2015).

In endodontics, the indications of antimicrobials are even more restricted, being reserved for situations where there is the presence of immunosuppression, the systemic impairment of the individual, inefficacy of surgery, and the involvement of neighboring soft tissues with spread of infection via the fascial spaces (Aminoshariae, \& Kulild, 2016; Veitz-Keenan, \& De 
Bartolo, 2014). Antibiotic prophylaxis in patients undergoing endodontic surgery has not shown statistically significant efficacy in preventing postoperative infection (Aminoshariae, \& Kulild, 2016; Moreno-Drada, \& García-Perdomo, 2016). In the present study, there were few antibiotic prescriptions after endodontic treatment. In another study, Maslamani and Sedeqi observed that $83.7 \%$ of dentists did not prescribe antibiotics during endodontic treatment, but they suggested that there is a need for more education about proper use of antibiotics (Maslamani, \& Sedeqi, 2018).

Bacterial resistance is considered a major concern in healthcare organizations. The abusive use of antimicrobials allows the appearance of modified microbial strains, reducing the effectiveness of treatments, increasing costs and generating greater morbidity and mortality for patients. The dentist should follow the current recommended guidelines for prescribing antibiotics, such as dosage, duration and duration of antibiotic use. The patient must be properly guided by the professional and informed about the need for antimicrobial therapy. The use of antibiotics does not dispense with infection prevention protocols and guidelines (Abushaheen et al. 2020; Stein, Farmer, Singhal, Marra, Sutherland, \& Quiñonez, 2018; World Health Organization, 2018).

Anti-inflammatory drugs should only be indicated in trauma caused by instrumentation, surgery or other causes, when the clinical manifestations (pain, edema, trismus, functional limitation) outweigh the benefit of tissue regeneration determined by the inflammatory reaction. In infections, the inflammatory reaction represents an immune defense mechanism. Under these conditions, the use of anti-inflammatory agents is not justified and should give way to specific antimicrobial chemotherapy. Anti-inflammatory drugs can mask the signs and symptoms of infection and delay diagnosis and treatment. (Delbet-Dupas, Devoize, Mulliez, Barthélémy, \& Pham Dang, 2021; Wannmacher, \& Ferreira, 2007).

As a limitation of the study, the prescription pattern of specialized dental care centers was determined only through the prescriptions received by the patients, and it was not possible to compare them with the patients' clinical history and the procedure performed. In addition to this limitation, dentists working in the services were aware of the days of the interviews conducted by the researchers. This fact could have influenced the prescription of medications. The data from this study are relevant because it is the first study to evaluate the pattern of medication prescription in specialized dental care centers in southern Brazil.

\section{Conclusion}

The prescription pattern in specialized dental care centers of the public health system showed deficiencies according to the protocols of regulatory agencies. Acetaminophen, ibuprofen and amoxicillin were the most prescribed medications. There was a high rate of prescriptions of oral antibiotics, suggesting that dentists may contribute to antibiotic resistance.

Educational institutions, linked to specialized dental centers, can develop strategies for the continuing education of professionals in the health network. Dentists and other health professionals, in turn, need to guide patients on the correct indication and administration of the use of medicines in dentistry, especially antibiotics and anti-inflammatory drugs. Responsible authorities should be aware of the need for improvements in the drug prescribing practices of oral health care providers in the public health system.

Future studies, which consider the prescription pattern associated with the patient's clinical condition and the intervention performed, may support the development of guidelines for the indication and administration of medication regimens. This would allow for systematic and continuous monitoring of medication prescriptions within specialized dental centers, reducing costs and ensuring effectiveness and safety for patients. 


\section{Acknowledgments}

We thank the Technical Area of Oral Health, Porto Alegre, RS, Brazil and Specialized Dental Centers, Porto Alegre, RS, Brazil. Dr. A. Leyva (USA) helped with English translation of the manuscript.

\section{References}

Abushaheen, M. A., Muzaheed, Fatani, A. J., Alosaimi, M., Mansy, W., George, M., Acharya, S., Rathod, S., Divakar, D. D., Jhugroo, C., Vellappally, S., Khan, A. A., Shaik, J., \& Jhugroo, P. (2020). Antimicrobial resistance, mechanisms and its clinical significance. Disease-a-month: DM, 66(6), 100971.

Ahsan, S., Hydrie, M., Hyder Naqvi, S., Shaikh, M. A., Shah, M. Z., \& Jafry, S. (2020). Antibiotic prescription patterns for treating dental infections in children among general and pediatric dentists in teaching institutions of Karachi, Pakistan. PloS one, 15(7), e0235671.

Al-Haroni, M., \& Skaug, N. (2007). Incidence of antibiotic prescribing in dental practice in Norway and its contribution to national consumption. The Journal of antimicrobial chemotherapy, 59(6), 1161-1166.

Aminoshariae, A., \& Kulild, J. C. (2016). Evidence-based recommendations for antibiotic usage to treat endodontic infections and pain: A systematic review of randomized controlled trials. Journal of the American Dental Association (1939), 147(3), 186-191.

Arteagoitia, I., Diez, A., Barbier, L., Santamaría, G., \& Santamaría, J. (2005). Efficacy of amoxicillin/clavulanic acid in preventing infectious and inflammatory complications following impacted mandibular third molar extraction. Oral surgery, oral medicine, oral pathology, oral radiology, and endodontics, 100(1), e11-e18.

Ataoğlu, H., Oz, G. Y., Candirli, C., \& Kiziloğlu, D. (2008). Routine antibiotic prophylaxis is not necessary during operations to remove third molars. The British journal of oral \& maxillofacial surgery, 46(2), 133-135.

Brasil. Ministério da Saúde. (2013). Protocolo de Segurança na Prescrição, uso e Administração de Medicamentos. Agência Nacional de Vigilância Sanitária (ANVISA). https://portaldeboaspraticas.iff.fiocruz.br/biblioteca/protocolo-de-seguranca-na-prescricao-uso-e-administracao-de-medicamentos/

Castilho, L. S., Paixão, H. H., \& Perini, E. (1999). Prescrição de medicamentos de uso sistêmico por cirurgiões-dentistas, clínicos gerais [Prescription of drugs of systemic use by dentists]. Revista de saude publica, 33(3), 287-294.

Dar-Odeh, N. S., Abu-Hammad, O. A., Al-Omiri, M. K., Khraisat, A. S., \& Shehabi, A. A. (2010). Antibiotic prescribing practices by dentists: a review. Therapeutics and clinical risk management, 6, 301-306.

De-Paula, K. B., Silveira, L. S., Fagundes, G. X., Ferreira, M. B., \& Montagner, F. (2014). Patient automedication and professional prescription pattern in an urgency service in Brazil. Brazilian oral research, 28, S1806-83242014000100250.

Delbet-Dupas, C., Devoize, L., Mulliez, A., Barthélémy, I., \& Pham Dang, N. (2021). Does anti-inflammatory drugs modify the severe odontogenic infection prognosis? A 10-year's experience. Medicina oral, patologia oral y cirugia bucal, 26(1), e28-e35.

Hupp, J. R., Ellis III, E., \& Tucker, M. R. (2015). Contemporary oral and maxillofacial surgery (6 ${ }^{\text {th }}$ ed.). Rio de Janeiro: Elsevier.

Hussein, R. J., Krohn, R., Kaufmann-Kolle, P., \& Willms, G. (2017). Quality indicators for the use of systemic antibiotics in dentistry. Zeitschrift fur Evidenz, Fortbildung und Qualitat im Gesundheitswesen, 122, 1-8.

Kaczmarzyk, T., Wichlinski, J., Stypulkowska, J., Zaleska, M., Panas, M., \& Woron, J. (2007). Single-dose and multi-dose clindamycin therapy fails to demonstrate efficacy in preventing infectious and inflammatory complications in third molar surgery. International journal of oral and maxillofacial surgery, 36(5), 417-422.

Keestra, J. A., Grosjean, I., Coucke, W., Quirynen, M., \& Teughels, W. (2015). Non-surgical periodontal therapy with systemic antibiotics in patients with untreated chronic periodontitis: a systematic review and meta-analysis. Journal of periodontal research, 50(3), 294-314.

Koyuncuoglu, C. Z., Aydin, M., Kirmizi, N. I., Aydin, V., Aksoy, M., Isli, F., \& Akici, A. (2017). Rational use of medicine in dentistry: do dentists prescribe antibiotics in appropriate indications?. European journal of clinical pharmacology, 73(8), 1027-1032.

Lacasa, J. M., Jiménez, J. A., Ferrás, V., Bossom, M., Sóla-Morales, O., García-Rey, C., Aguilar, L., \& Garau, J. (2007). Prophylaxis versus pre-emptive treatment for infective and inflammatory complications of surgical third molar removal: a randomized, double-blind, placebo-controlled, clinical trial with sustained release amoxicillin/clavulanic acid (1000/62.5 mg). International journal of oral and maxillofacial surgery, 36(4), $321-327$.

Lei $n^{\circ} 9.787$ de 10 de fevereiro de 1999. (1999). Altera a Lei no 6.360, de 23 de setembro de 1976, que dispõe sobre a vigilância sanitária, estabelece o medicamento genérico, dispõe sobre a utilização de nomes genéricos em produtos farmacêuticos e dá outras providências. Presidência da República.

Lisboa, S. M., Martins, M. A., Castilho, L. S., Souza e Silva, M. E., \& Abreu, M. H. (2015). Prescribing errors in antibiotic prophylaxis by dentists in a large Brazilian city. American journal of infection control, 43(7), 767-768.

Mainjot, A., D'Hoore, W., Vanheusden, A., \& Van Nieuwenhuysen, J. P. (2009). Antibiotic prescribing in dental practice in Belgium. International endodontic journal, 42(12), 1112-1117.

Maslamani, M., \& Sedeqi, F. (2018). Antibiotic and Analgesic Prescription Patterns among Dentists or Management of Dental Pain and Infection during Endodontic Treatment. Medical principles and practice: international journal of the Kuwait University, Health Science Centre, 27(1), 66-72.

Mombelli, A., Almaghlouth, A., Cionca, N., Courvoisier, D. S., \& Giannopoulou, C. (2015). Differential benefits of amoxicillin-metronidazole in different 
phases of periodontal therapy in a randomized controlled crossover clinical trial. Journal of periodontology, 86(3), 367-375.

Moreno-Drada, J. A., \& García-Perdomo, H. A. (2016). Effectiveness of Antimicrobial Prophylaxis in Preventing the Spread of Infection as a Result of Oral Procedures: A Systematic Review and Meta-Analysis. Journal of oral and maxillofacial surgery: official journal of the American Association of Oral and Maxillofacial Surgeons, 74(7), 1313-1321.

Palmer, N. A., Pealing, R., Ireland, R. S., \& Martin, M. V. (2000). A study of prophylactic antibiotic prescribing in National Health Service general dental practice in England. British dental journal, 189(1), 43-46.

Palmer, N. O., Martin, M. V., Pealing, R., \& Ireland, R. S. (2000). An analysis of antibiotic prescriptions from general dental practitioners in England. The Journal of antimicrobial chemotherapy, 46(6), 1033-1035.

Portaria $n^{\circ} 834$ de 14 de maio de 2013. (2013). Redefine o Comitê Nacional para a Promoção do Uso Racional de Medicamentos no âmbito do Ministério da Saúde. Ministério da Saúde. https://bvsms.saude.gov.br/bvs/saudelegis/gm/2013/prt0834_14_05_2013.html

Porto Alegre. Secretaria Municipal de Saúde. (2020). Relação Municipal de Medicamentos Essenciais (REMUME). http://lproweb.procempa.com.br/pmpa/prefpoa/sms/usu_doc/remume2020.pdf

Poveda Roda, R., Bagán, J. V., Jiménez Soriano, Y., \& Gallud Romero, L. (2007). Use of nonsteroidal antiinflammatory drugs in dental practice. A review. Medicina oral, patologia oral y cirugia bucal, 12(1), E10-E18.

Rauniar, G. P., Das, B. P., Manandhar, T. R., \& Bhattacharya, S. K. (2012). Effectiveness of an educational feedback intervention on drug prescribing in dental practice. Kathmandu University medical journal (KUMJ), 10(40), 30-35.

Ren, Y. F., \& Malmstrom, H. S. (2007). Effectiveness of antibiotic prophylaxis in third molar surgery: a meta-analysis of randomized controlled clinical trials. Journal of oral and maxillofacial surgery: official journal of the American Association of Oral and Maxillofacial Surgeons, 65(10), $1909-1921$.

Segura-Egea, J. J., Velasco-Ortega, E., Torres-Lagares, D., Velasco-Ponferrada, M. C., Monsalve-Guil, L., \& Llamas-Carreras, J. M. (2010). Pattern of antibiotic prescription in the management of endodontic infections amongst Spanish oral surgeons. International endodontic journal, 43(4), 342-350.

Stein, K., Farmer, J., Singhal, S., Marra, F., Sutherland, S., \& Quiñonez, C. (2018). The use and misuse of antibiotics in dentistry: A scoping review. Journal of the American Dental Association (1939), 149(10), 869-884.e5.

Teoh, L., Stewart, K., Marino, R., \& McCullough, M. (2018). Antibiotic resistance and relevance to general dental practice in Australia. Australian dental journal, 63(4), 414-421.

Thompson, W., Rios, L. E., Fedorowicz, Z., Dailey, Y., \& Douglas, G. (2018). I've got Toothache, I need Antibiotics: a UK Perspective on Rational Antibiotic Prescribing by Dentists. Brazilian dental journal, 29(4), 395-399.

Veitz-Keenan, A., \& De Bartolo, A. M. (2014). Insufficient evidence of the effect of systemic antibiotics on adults with symptomatic apical periodontitis or acute apical abscess. Evidence-based dentistry, 15(4), 104-105.

Wannmacher, L., \& Ferreira, M. B. C. (2007). Farmacologia clínica para dentistas (3. ed.). Rio de Janeiro: Guanabara Koogan.

World Health Organization. (1993). How to investigate drug use in health facilities: selected drug use indicators. https://www.who.int/publications/i/item/whodap-93.1

World Health Organization. (2018). Report on surveillance of antibiotic consumption: 2016-2018 early implementation. https://apps.who.int/iris/bitstream/handle/10665/277359/9789241514880-eng.pdf 